\title{
22 STRUCTURANTION IN RESEARCH AND PRACTICE: Representing Actor Networks, Their Structurated Orders and Translations
}

\author{
Laurence Brooks \\ Chris Atkinson \\ Brunel University
}

\begin{abstract}
This paper sets out to describe how the StructurANTion theoretical framework and tools derived from it can be used to represent translations of humanchine actor networks and their structurated orders, to underpin both research and practice in integrating IS and organizational transformation.
\end{abstract}

Keywords: Structuration theory, actor network theory, humanchine, translations, patientcentered information system

\section{INTRODUCTION}

This paper sets out to illustrate how, within the StructurANTion framework, an existing humanchine actor network, the actors within it, its information system component, and its associated Structurated order are translated from one network into another. To do this a number of instruments that capture the translation of a network are introduced and illustrated.

The proposition is that such translations occur when an emergent focal actor (or actors) within a humanchine actor network invoke the emancipatory structure inherent within all Structurated actor networks. This extends the concept (Atkinson and Brooks 2003) of actor networks as being Structurated hybrid societies of humans and nonhumans. As such it is part of an ongoing project to deploy social and socio-technical theories as mutable conceptual actors for use within the field of organizational and social information systems (IS) as a research discipline and concrete real-world practices. We wish to contribute to, but in no way fully address, the provocative question posed for this 
conference as to whether theory can really inform IS practice. Therefore, our approach is to explore the role of social theory in IS and the contribution of the IS field toward social research. This is accomplished by integrating two of the strong social theory candidates already deployed in IS research: structuration theory (ST) and actor network theory (ANT). Our illustration draws on a case study based on a project undertaken within the breast surgery unit of a UK National Health Service (NHS) hospital.

\section{STRUCTURATION AND ACTOR NETWORK THEORY}

Given the constraints of a conference paper and the conceptual complexity of both ST and ANT, it is not possible here to give a full account of StructurANTion's two constituent theories. It will therefore be assumed that the reader has some familiarity with structuration theory (Giddens 1979, 1984a) and actor network theory (ANT) (Callon 1986; Latour 1999). Particularly as they have not gone unnoticed or under-used within the IS research community. The former is cited by Jones and Karsten (2003) as having been deployed in 225 IS related papers/studies over the past 15 years, the latter as having been increasingly internationally deployed and cited within IS research journals and conference papers by those undertaking interpretive analyses of IS-related interventions (Tatnall and Gilding 1999; Walsham 1997). We argue that both are playing an important role in the emergence of IS as a significant academic discipline.

A more detailed description of StructurANTion theory and how the two constituent theories relate to this proposed theoretical hybrid is provided by Atkinson and Brooks (2003).

The main feature of ST drawn on in this paper is the recursive relationship between a person's psychologically located structures of domination, legitimation, and signification (Giddens 1979) that (mediated through their cognitive modalities) they draw on for their agency and interactions with others. It is the aggregations and combinations of these structures within the actions of millions of people that make up social systems and their institutions. The nature of such structurally mediated agency is highly routinized, resulting in stable social systems and interpersonal relationships. As a result, these social systems recursively persist over time and space. However, they do not always stay the same, as a consequence of an individual's capability for reflexive monitoring of their own and others' actions. Combining this with the unintended consequences of such actions, these social systems gradually change over time and space.

In contrast, the salient aspect of ANT is the manner in which humans and machines (or nonhumans) respond to a problem and are abruptly translated, through the machinations of a focal actor, into hybrid humanchine actor networks. Actor network translation with its moments of problematization, intéressemment, enrolment, and mobilization will be central to this paper. The manner in which focal actors seek to inscribe their interests into the network, to address a problem they have identified as salient, is important. Through successive translations, actor networks (humanchines) display increasingly concerted agency, robust organization, and identity. They become increasingly black-boxed. This is often achieved through the coordinating role of technologies. Such networks and their actors are, however, always under threat of being 
themselves translated by more powerful focal actors into other networks. Networks are also networks of other networks (Latour 2001). They are often in contention with each other, seeking constantly to translate each other. It is these features of network translation that will be the central theme of this paper.

\section{CONSTRUCTING THE STRUCTURANTION HYBRID}

This section discusses the arguments behind the bringing together of StructurANTion's two constituent theories of ST and ANT. It identifies StructurANTion theory as a mutable conceptual device, not only capable of forming alliances with people to interpret the world but, through such alliances, one potentially capable of affecting agency.

Atkinson and Brooks (2003) have already discussed the procedural grounds (the how rather than substantial why) that support the melding of ST and ANT to form StructurANTion. These are founded in the discussions of the nature and role of social theory by Giddens with respect to ST and by Law and Urry (2002) with respect to ANT. Giddens observes that is possible to use theory "not only to understand the world, but as a cognitive device with which to change it" (Giddens 1979; emphasis added). Giddens conceives of this as the workings of the double hermeneutic. People interpret theory and mutate it, using it as a cognitive device, a conceptual mechanism, a conceptual actor, to inform human understanding of the world and to underpin their agency. Law and Urry also acknowledge that theory is a conceptual artifact, one that is capable of being enrolled and translated into a real world humanchine network and used as a mutable theoretical actor "that can help to bring into being what it supposedly discovers."

What is advocated by these authors is no less than the social shaping of theory or given a device like the nature of theory the social shaping of a cognitive technology. When translated into the real world, ST and ANT can be seen by their progenitors and these author's as mutable mobiles (Law and Mol 2000). Mutable mobiles are actors (artifacts) capable of being translated; metamorphosed, melded, and mobilized in response to prevailing circumstances. Through an exercise of the double hermeneutic, in alliance with human actors, they are not only a means of understanding the world but of changing it.

How has StructurANTion come about? StructurANTion has come into being as a theoretical actor through the mutation and conjoining of its two progenitor theories by this paper's authors. They have pursued this by an alliance with, and application of, the double hermeneutic actor to ANT and ST. StructurANTion, like all other theories, is seen by the paper's authors, as itself a mutable mobile.

As to the substantive why grounds for melding the two theories into the StructurANTion theory hybrid: This is a deliberate exercise of the double hermeneutic. It is an attempt to gain both interpretive and practical leverage from being able to understand how socio-technical networks, societies of humans and nonhumans, come into being, persist, and change. The latter occurs in either a slow evolutionary, gradual, manner or (as will be explored later) in an abrupt transformational way. The double hermeneutic 
adopted here is, in ANT terms, itself a cognitive actor, a device, a stratagem of theory translation by the authors.

Together with people, in this case the authors, who enact it, the nonhuman technique that is the double hermeneutic makes up an interpretative humanchine (where a machine is the material manifestation of some form of technique) network whose intention is to mutate theory and demonstrate its use. This actor network, in turn, contributes to this paper artifact and its content of discursive actors. In turn, this network along with all its other actors in the academic paper production process, such as the laptop, the Internet, the English language, the traces of other authors and their papers, reviewers, editors, the review committee, the IFIP 8.2 authoring Web site, etc., all constitute the conference paper producing humanchine actor network. Such a humanchine actor network is itself a medium, or a machination (Latour 1987), convened for translating papers of an appropriate quality and participants into the conference's wider humanchine actor network, whose annual recurrence in turn makes up the collective actor network that is the IFIP 8.2 conference.

A humanchine within StructurANTion theory, from this example, is therefore the prime actor, a human and nonhuman duality that perpetrates agency. As Latour (1999) says, "Purposeful action and intentionality may not be properties of objects, but they are also not properties of humans either. They are properties of institutions [collectives of humans and nonhumans], apparatuses, or what Foucault called dispositifs." This we have designated here as humanchines. He also says, "It is not aircraft that fly people, but airlines," and more chillingly, "It is not guns or people that kill people, but people and guns that kill people," i.e., humanchines.

The neologism of the humanchine, as described here, is intended to convey and emphasize the entangling, even the interpenetration, of the human and nonhuman as the entity that acts. In the integration of the human with the machine it is the human/nonhuman artifact duality that constitutes the agency perpetrating actor. It is difficult to identify any instances where humans exhibit agency and socially interact, and where nonhumans, artifacts (in some form or other), are not present. Language alone is an all-pervasive artifact. In its oral, visually scripted, and signed manifestations it is the most fundamental and omnipresent of artifacts, mediated in many instances by information technologies. Along with people, language perpetrates agency and facilitates social intercourse.

The concept of the humanchine has been adopted to capture the duality of people and artifacts that constitute a collective, whose agency and trajectory is more than the sum of its constituent actors (Latour 1999). There may be only one human and one machine in a humanchine networked duality as in the case of the Latour's "gun-man" or there may be thousands, as in the case of an airline. No matter how many are involved, it is this all pervasive humanchine duality that is at the center of StructurANTion theory and that perpetrates action. They also constitute information systems.

Such collectives not only endure over space and time, but also change, usually imperceptibly, although sometimes dramatically, as new humanchine organizational networks emerge. The airline that a conference participant translates into by becoming a passenger in order to fly to a conference is not the same as the one first encountered five weeks prior when the flight was booked, never mind five years later. Yet, like IFIP 8.2 itself, it lives on as a complex humanchine networked actor. 
Such humanchine networks, however, do not sustain themselves solely through the, often Machiavellian, stratagems of the focal actor who brought such organizational networks, societies of people and artifacts, into being in the first place. In the case of the airline, this was most probably a now deceased aviator entrepreneur or a corporate buyout. There have to be mechanisms inherent in the routinized relationships and agency perpetrated by the animate and non-animate actors that constitute humanchines, whether they are an airline or a conference, which secures these networks' existence, over time, yet enables them also to change. This raises the questions, by what processes do complex collective humanchines, people, and technologies persist yet change gradually? This, in turn, prompts the obverse question. What are the mechanisms that come into play when such networks are transformed dramatically?

To explore this phenomenon and to address these questions, the authors, in league with the conceptual device that is Giddens' double-hermeneutic have engaged in an exercise of Law and Urry's theory mutation. The StructurANTion theoretical hybrid is the outcome of this exercise.

\section{THE STRUCTURANTION THEORY HYBRID}

In this section we explore which specific features of the progenitor theoretical actors of structuration theory and actor network theory have been drawn on and why (see Figure 1), as well as what has been co-opted from elsewhere. In a later section we shall explore how such hybrid humanchine networks, including their information systems, are translated from one into another.

As examples, the airline and IFIP 8.2, cited above, are two ends of the network spectrum. One is highly ordered, socially stratified, functionally complex, and physically located, while the other is very fluid in form, functionally simple, socially much less stratified and non-located, almost virtual. Yet both are constituted out of people and artifacts that interact together and show combined agency, persist, and change. What then does a theoretical hybrid need to extract from ANT and ST to provide an ontology that is a cogent theoretical description of both organizational networks?

ANT shows us how humans and the nonhuman come together to form organizational actor networks that exhibit agency, whereas ST does not; it only sanctions the existence of human actors. Conversely, ANT has no concept of a network of humans and nonhumans as having any form of intrinsic inherent structures binding it together, enabling through reflexivity actor agency and interactions.

Within ANT, the network's actor's communications, sanctions, and power are not mediated by commonly shared modalities and structures; networks are relationally fiat. A network is bound together (if by anything) by a controlling focal actor who aligns all the other actors' interests with theirs through the moments of translation and on whose behalf it acts. ST does address networks, through the recursive cycle of agency and, modally mediated, cognitive structures, but only with respect to humans. If we combine the two theories together we get a structurated, persistent human/machine network that exhibits agency. There is a problem with this as nonhumans do not have minds and therefore cannot host ST structures.

Structures, according to Giddens, only exist in peoples' minds. They autonomically facilitate human agency and therefore change intrinsically as that human agency changes, 


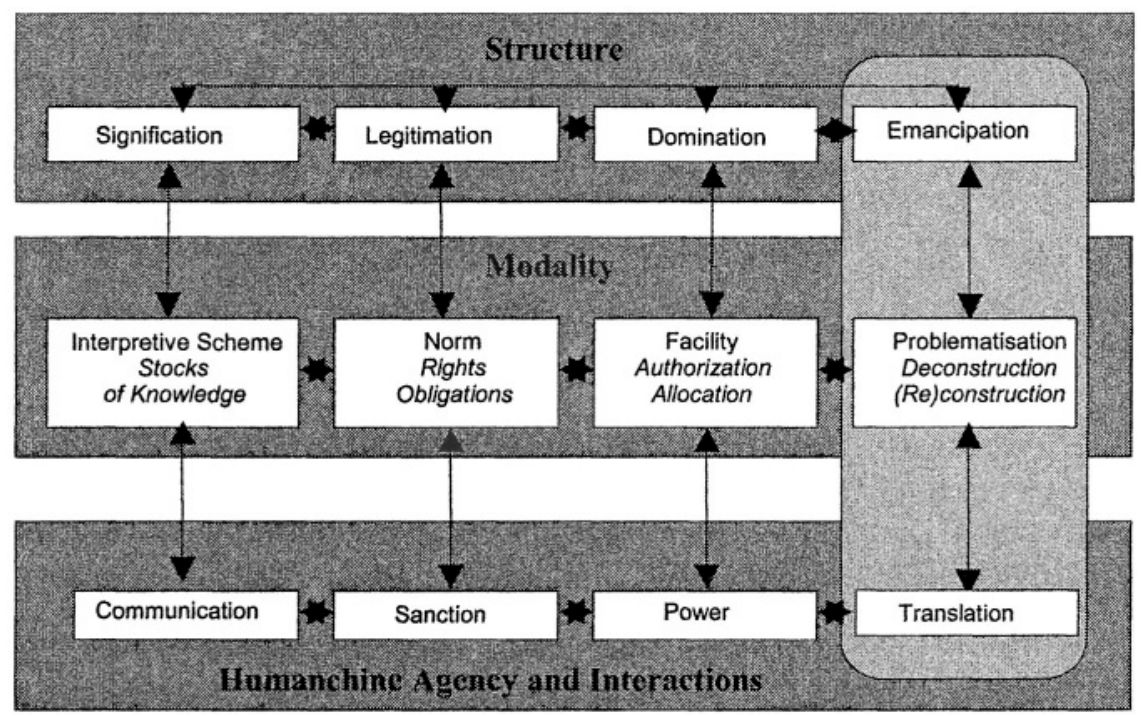

Figure 1. The Structures, Modalities, and Agency of Actors Within the StructurANTion Framework

in response to external events and the actor's recursive and reflexive monitoring of them. They are therefore directly inaccessible. Social structures within ST change as a result of a human's autonomic, unconsciously mediated reflexivity, not by conscious reflection. Conversely, modalities are far more accessible as they manifest themselves in the individual or collective human actions. People can recount, through discursive consciousness (Giddens 1984b) how they and their fellow actors deploy their actions, their stocks of knowledge, their rights and obligations, as well as their capacity to authorize others actions and allocate resources.

By observing modalities as they manifest themselves in their collective agency and other actor's responses, we can infer what they are. They also manifest themselves through mediating artifacts, in documentation, and in formalizations of action, for example clinical protocols, as well as in the formal and informal rules of behavior, in particular social and organizational settings. They can also be accessed through human actors' discursive consciousness, getting people within a network to talk about their work and the manner in which they interact. Through such approaches we can, to some degree, surface these modalities as requirements that any prospective technology has to accommodate and hopefully enhance. These can then be built into machines, including information technologies. If adopted and effective, they will replicate, expand, and augment existent human, agency, and modalities as well as other machine functionalities. They may also provide opportunities for new forms of humanchine agency. Humans may be persuaded through interaction with the technology to change their agency and hence effect change in their modalities and structures (e.g., mobile phones). Jones (1999) calls this process "the double mangle."

Within StructurANTion, to be functionally effective and persist, humanchine networks are integrated within organizations at the point of agency through an alignment 
of their human and machine modalities. As a result, they replicate the organizational network's existing structures of signification, legitimation, and domination. Within organizations these constitute structurated orders, with modalities shared by actors. Each act by an actor in the network reinforces the existing structurated order's forms of signification, legitimation and domination. While the network's actor's behaviors may change their structural relationships, their structurated order remains the same. This begs the question: How then do such networks fundamentally change their structurated order?

Structuration relies on change being an emergent property of widespread individual agency/structure relationships and the unintended consequences of their actions. In doing so it reinforces the existing structurated order or possibly changes it incrementally. ANT, on the other hand, relies on some form of focal actor, either human or nonhuman, to drive change and the actors in the network together, subsequent to its translation through an alignment of actor interests. This necessitates human and nonhuman actors traversing one or a series of (in ANT terms) obligatory passage points. Such change is often dramatic, a step change.

As an alternative to replicating existing structures through the modalities within technologies, we can construct machines to be machinations. Such machine machinations have the focal actor's desired modalities and anticipated forms of future humanchine agency "built" into them. Instead of melding with the existing structurated order, the IS acts as a fulcrum around which change is levered. In alliance with machine machinations, the focal actor seeks to perpetrate changes through exerting power and political agency in order to bring agency, modalities, and ultimately structures of the human and other technologies in line with those built into their technology. Latour (1987) reflects,

The simplest means of transforming the juxtaposed set of allies into a whole that acts as one is to tie the assembled forces to one another, that is to build a machine. A machine as its name implies, is first of all, a machination, a stratagem, a kind of cunning, where borrowed forces keep one another in check so that none can fly apart from that group.

This has already been identified and argued to involve evoking what has been termed the emancipatory structure (Atkinson and Brooks 2003), which is inherent within the structurated order of every network (see Figure 1). This structure, unlike the others, is drawn on by an actor who seeks to be a focal actor (either as an individual or a collective of human and nonhuman actors) of a new network, one that addresses the issues they have identified as arising from the existing network's behaviors as founded on what they problematize as the unacceptable modalities of the existing structurated order. It originates when an actor problematizes not just network behaviors but its underpinning structurated order and seeks to replace both with a new network.

The concept of emancipation has in the last 200 years been taken to refer to freedom from slavery or Marx's capitalist oppression and class struggle. However, in its more general sense, as we are using here, it is defined as "the setting free from legal, social, or political restraint" (Newton 2003). So the translation of a humanchine network entails 
setting the human and nonhuman actors free from their current structurated orders and (through traversing the moments of translation by which a network comes into being) reestablishing these actors within it. This applies to existing actors. New actors, such as an IS, could be developed, in situ, within the network or brought in through procurement processes.

In the next section we explore the translation of the structurated order of a clinical decision-making network, encompassing information systems along with people.

\section{TRANSLATING STRUCTURATED ORDERS}

In order to better understand the ideas being presented, this section discusses the translation of a humanchine actor network, the agency of actors from which it is constituted, and the structurated order that the actors in the network recursively reproduce. The following example draws on action research undertaken within a UK hospital (Atkinson 1997). That research studied the entire breast cancer surgical service network and the prospective role of a to-be-procured, hospital-wide clinical IS. This was undertaken on behalf of the UK NHS Executive (Atkinson 1997; Atkinson and Peel 1998) as part of a project exploring the nature and scope of the electronic patient record. Initially the focus is the structurated order of a clinician-led breast cancer decisiontaking actor network, captured in Figure 2 and explored in Table 1.

The existing structurated order of this network had been a physician-centered breast cancer service and was being challenged, problematized, and transformed by sympathetic clinicians and patient representations. Power over treatment decisions had resided with oncologists and surgeons. However, enlightened clinicians and patient advocates were challenging this situation. As part of a major hospital-wide IS procurement, they wanted to inscribe a patient- centered approach to care into the new application.

What was happening within the hospital was both a social and technical change leading to a new structurated order. Their scoping and procurement of a new patientcentered information system (PCIS), with patient-centered clinical protocols, was intended to support and reinforce a new women (and male) patient-centered service. They were pursuing this, we would argue, by their drawing on the emancipatory structure latent within the structurated orders of all networks, as set out within the StructurANTion theory (Atkinson and Brooks 2003). The narrative of this transformation from a physician to patient-centered service, the actors, and their behaviors, is illustrated in Table 2. This sets out the activities of the actors as they initially problematize and subsequently deconstruct the existing network with its cliniciancentered structurated order. This subsequently leads to the (re)construction of a new patient-centered actor network and the emergence of a patient-centered breast cancer clinical-decision making process and structurated order (see Figure 3 and Table 3).

The following section details the steps by which a transformation might be seen to be taking place. As with all theory, the search is for a way in which to make it useful/useable. While these are broad stages, they provide an understanding of the change pathways, with the intention that future work will provide tools and support for effecting or at least affecting these transformations. 


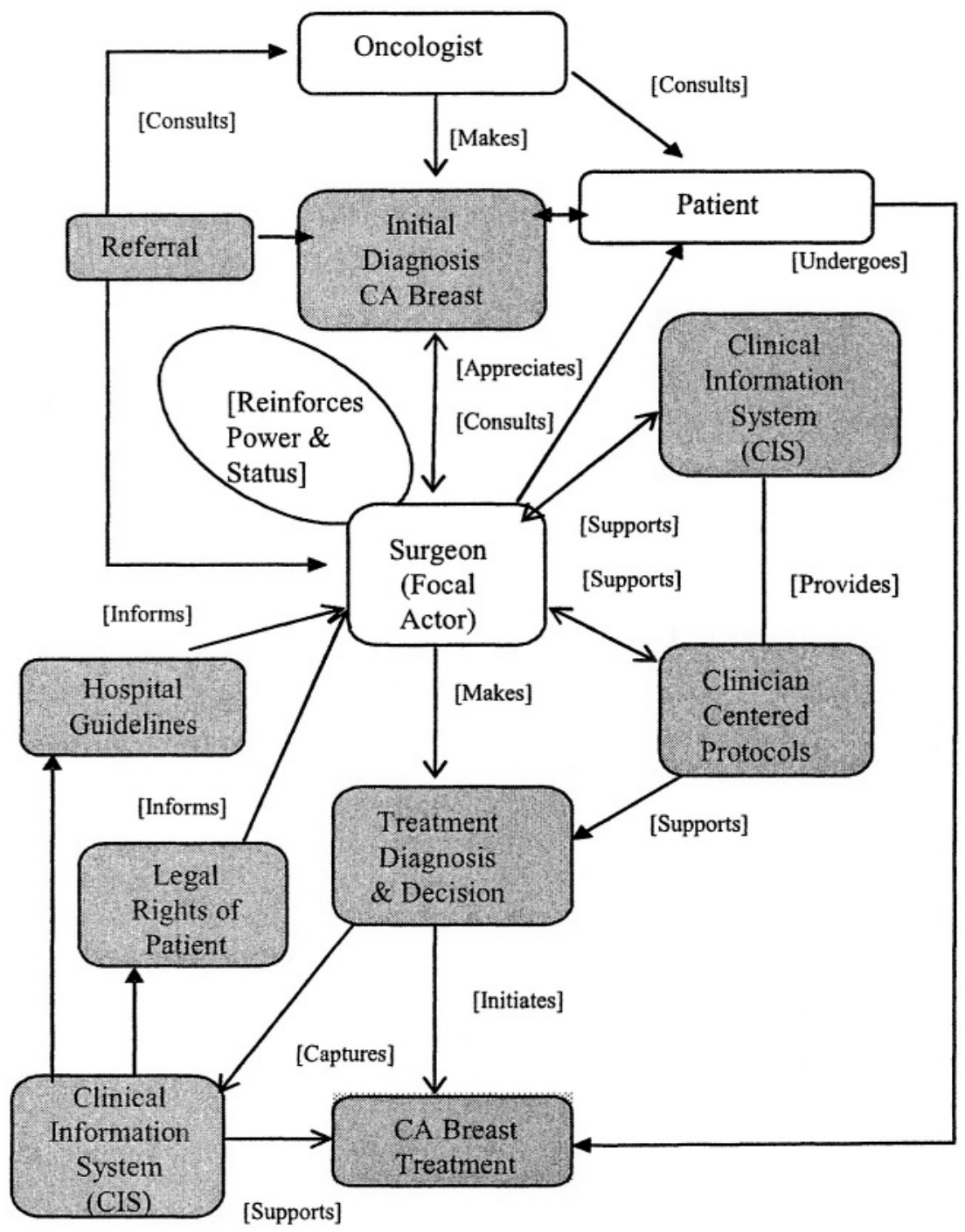

Figure 2. Clinician-Humanchine Breast Cancer Treatment Decision-Making Actor Network (human actors are shown not shaded) 
Table 1. Structurated Order of Clinician-Centered Humanchine Breast Cancer Treatment (Human actor $=$ not shaded. . Artifact actor $=$ shaded)

\begin{tabular}{|c|c|c|c|}
\hline Structure & Signification & Legitimation & Domination \\
\hline Actor & $\begin{array}{l}\text { Interpretive Scheme } \\
\text { Stocks of Knowledge }\end{array}$ & $\begin{array}{c}\text { Norm } \\
\text { Rights \& Obligations }\end{array}$ & $\begin{array}{c}\text { Facility } \\
\text { Authorization Allocation }\end{array}$ \\
\hline GP Referral & $\begin{array}{l}\text { GP referral in } \\
\text { clinical terminology } \\
\text { drawing clinical } \\
\text { knowledge and of } \\
\text { the patient. }\end{array}$ & $\begin{array}{l}\text { Initiate process of } \\
\text { care; be appropriate } \\
\text { referral. }\end{array}$ & $\begin{array}{l}\text { Authorize and allocate } \\
\text { clinicians and resources. }\end{array}$ \\
\hline Oncologist & $\begin{array}{l}\text { Clinical knowledge } \\
\text { diagnostic expertise } \\
\text { skills expressed in } \\
\text { clinical terms and } \\
\text { language. }\end{array}$ & $\begin{array}{l}\text { Make an appropriate } \\
\text { diagnosis on behalf of } \\
\text { patient. To assess/add } \\
\text { patient information. } \\
\text { Ensure that diagnosis } \\
\text { is in line with current } \\
\text { practice and } \\
\text { protocols. }\end{array}$ & $\begin{array}{l}\text { Authorize resources to } \\
\text { support diagnosis. } \\
\text { Allocate clinical exper- } \\
\text { tise to support diagnosis. } \\
\text { Allocate patient to a } \\
\text { surgeon for diagnosis/ } \\
\text { treatment. }\end{array}$ \\
\hline Patient & $\begin{array}{l}\text { Lay knowledge and } \\
\text { experience of disease } \\
\text { and its } \\
\text { consequences. }\end{array}$ & $\begin{array}{l}\text { Receive and comply } \\
\text { with clinically appro- } \\
\text { priate diagnosis and } \\
\text { treatment. Entitled to } \\
\text { a second opinion. }\end{array}$ & $\begin{array}{l}\text { No capacity to allocate } \\
\text { or authorize resources. } \\
\text { Clinical personnel } \\
\text { allocate resources on } \\
\text { their behalf. }\end{array}$ \\
\hline $\begin{array}{l}\text { Surgeon (Focal } \\
\text { Actor) }\end{array}$ & $\begin{array}{l}\text { Clinical stocks of } \\
\text { knowledge to under- } \\
\text { pin diagnosis and } \\
\text { treatments. }\end{array}$ & $\begin{array}{l}\text { Make a diagnosis on } \\
\text { behalf of the patient } \\
\text { and identify a } \\
\text { clinically appropriate } \\
\text { treatment. }\end{array}$ & $\begin{array}{l}\text { Authorize and allocate } \\
\text { cognitive and diagnostic } \\
\text { resources to identify, } \\
\text { make diagnosis, and } \\
\text { treat their patient. }\end{array}$ \\
\hline $\begin{array}{l}\text { Clinical Infor- } \\
\text { mation System } \\
\text { (CIS) }\end{array}$ & $\begin{array}{l}\text { Clinical and patient } \\
\text { information avail- } \\
\text { able in clinical and } \\
\text { managerial forms. }\end{array}$ & $\begin{array}{l}\text { Provide and capture } \\
\text { patient information. } \\
\text { Provide clinician } \\
\text { access to CA breast } \\
\text { diagnosis protocols } \\
\text { and capture diagnosis } \\
\text { and treatment. }\end{array}$ & $\begin{array}{l}\text { Allocate clinical } \\
\text { information and } \\
\text { protocols and capture } \\
\text { compliance (or variant) } \\
\text { behaviors by other } \\
\text { actors. }\end{array}$ \\
\hline $\begin{array}{l}\text { Diagnosis of } \\
\text { CA Breast }\end{array}$ & $\begin{array}{l}\text { Expressed in clinical } \\
\text { terms. }\end{array}$ & $\begin{array}{l}\text { To be addressed via } \\
\text { clinically appropriate } \\
\text { treatment. }\end{array}$ & $\begin{array}{l}\text { Authorize, allocate } \\
\text { clinical resources to } \\
\text { capture and address } \\
\text { diagnosis. }\end{array}$ \\
\hline $\begin{array}{l}\text { Clinician- } \\
\text { Centered } \\
\text { Protocols }\end{array}$ & $\begin{array}{l}\text { Expressed in clinical } \\
\text { terms. }\end{array}$ & $\begin{array}{l}\text { To have compliance } \\
\text { demonstrated. To } \\
\text { provide clinicians } \\
\text { with appropriate } \\
\text { diagnostic procedures. } \\
\text { o have compliance } \\
\text { demonstrated }\end{array}$ & $\begin{array}{l}\text { In league with oncolo- } \\
\text { gist and surgeon } \\
\text { formulate diagnosis and } \\
\text { treatment decision and } \\
\text { capture compliance. }\end{array}$ \\
\hline
\end{tabular}




\begin{tabular}{|l|l|l|l|}
\hline \multicolumn{1}{|c|}{ Structure } & \multicolumn{1}{c|}{ Signification } & \multicolumn{1}{c|}{ Legitimation } & \multicolumn{1}{c|}{ Domination } \\
\hline Actor & $\begin{array}{l}\text { Modality } \\
\text { Stocks of Knowledge }\end{array}$ & $\begin{array}{l}\text { Norm } \\
\text { Rights \& Obligations }\end{array}$ & $\begin{array}{c}\text { Facility } \\
\text { Authorization Allocation }\end{array}$ \\
\hline $\begin{array}{l}\text { Hospital } \\
\text { Guidelines }\end{array}$ & $\begin{array}{l}\text { Inscribed in clinical } \\
\text { and administrative } \\
\text { ternns. }\end{array}$ & $\begin{array}{l}\text { To be complied with } \\
\text { and support hospital } \\
\text { in avoiding litigation. }\end{array}$ & $\begin{array}{l}\text { Mitigate patient litiga- } \\
\text { tion by authorizing } \\
\text { clinician compliance. }\end{array}$ \\
\hline $\begin{array}{l}\text { Legal Rights of } \\
\text { Patient }\end{array}$ & $\begin{array}{l}\text { Inscribed in legal/ } \\
\text { legislative } \\
\text { languages. }\end{array}$ & $\begin{array}{l}\text { Provide patient with } \\
\text { information on their } \\
\text { legal rights obliga- } \\
\text { tions. }\end{array}$ & $\begin{array}{l}\text { Allocate to the patient } \\
\text { certain rights with } \\
\text { respect to their hospital } \\
\text { treatment. }\end{array}$ \\
\hline $\begin{array}{l}\text { Treatment } \\
\text { Decision }\end{array}$ & $\begin{array}{l}\text { Expressed in clinical } \\
\text { terminology. }\end{array}$ & $\begin{array}{l}\text { Right to address } \\
\text { obligated to be } \\
\text { appropriate. }\end{array}$ & $\begin{array}{l}\text { Authorization of clinical } \\
\text { personnel and } \\
\text { allocation. }\end{array}$ \\
\hline Treatment & $\begin{array}{l}\text { Draws on clinical } \\
\text { knowledge and } \\
\text { language within } \\
\text { network actors. }\end{array}$ & $\begin{array}{l}\text { To provide the most } \\
\text { clinically appropriate } \\
\text { treatment against } \\
\text { diagnosis and } \\
\text { decision. }\end{array}$ & $\begin{array}{l}\text { Allocate resources and } \\
\text { allocate clinicians } \\
\text { necessary to patient } \\
\text { treatment. }\end{array}$ \\
\hline
\end{tabular}

\section{BREAST CANCER TREATMENT DECISION MAKING ILLUSTRATION}

The following illustrates a typical StructurANTional analysis of a translational change from a physician-centered to a patient-centered decision making context.

This happened in a hospital where the focal actor changed from being the clinical expert, accompanied by their protocols, IS, and technologies, to the patient. With help from sympathetic clinicians and managers, they deconstructed the existing network (see Figure 2), translated it, and then reconstructed it (see Figure 3). Employing a StructurANTional analysis of a network and its evolutionary changes, we have identified five broad stages.

Stage 1: Delineate how prior to translation the human and nonhuman actors in the existing network behave individually and in their relationships toward each other (Figure 2).

Stage 2: Identify the modalities of the structures of signification, legitimation, and domination of each actor in the network (Table 1).

Stage 3: Explore the emancipatory structure at work in the problematization of the existent actor network structurated order by a self appointed focal actor. This is manifest in the deconstruction and subsequent (re)constructional translation through the mobilization of actors and the emancipatory structure inherent within the network (Table 2).

Stage 4: Delineate how the actors in the newly emergent network behave individually and collectively and make manifest the new structurated order.

Stage 5: Identify the humans and machine artifacts of the actor network and their modalities within the newly emergent network and the structurated order they (re)produce (Figure 3). 
Table 2. The Emancipatory Structure in Action

\begin{tabular}{|c|c|}
\hline & Emancipatory Structure and Humanchine Translational Agency \\
\hline Start & Existing Actor Network - Physician Centered System \\
\hline 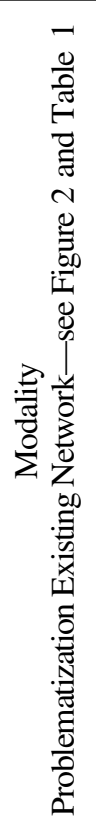 & $\begin{array}{l}\text { - Recognition and acknowledgment by patient group and sympathetic clinicians } \\
\text { that today current surgeon/consultant dominated breast cancer (BC) decision } \\
\text { making and delivery is untenable, unethical, and disempowering to those who } \\
\text { are in need of or currently undergoing surgical (and other forms treatment) as } \\
\text { well as maintenance and remedial treatment. } \\
\text { - Share this perception with other patients and with clinicians in the department } \\
\text { and hospital that would be or had the potential to be sympathetic to the idea of } \\
\text { patient-centered clinical decision making and treatment. } \\
\text { - Explore this situation and various perceptions of it as untenable with other } \\
\text { patient's and clinicians and other interested parties. } \\
\text { - Confirm this perception with other patient's and parties who would be } \\
\text { potential allies within the clinical body. } \\
\text { - Identify research sources of information on current practices in BC decision } \\
\text { making and the introduction of patient-centered services as a basis for creating } \\
\text { a vision of future services. } \\
\text { - Establish a case for confronting and addressing the current BC decision making } \\
\text { within the hospital department(s) for BC services and their delivery. } \\
\text { - Enroll politically other patients, managers, and clinicians into this point of } \\
\text { view. } \\
\text { - Explore how patient notes, clinical information system, protocols, and guide- } \\
\text { lines support clinical decision making and exclude the patient through limiting } \\
\text { access and the arcane clinical languages used }\end{array}$ \\
\hline 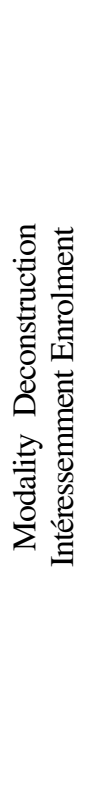 & $\begin{array}{l}\text { - Seek out powerful allies and stakeholders within and outside the organization } \\
\text { that share the same opinion with respect to current BC decision making practice } \\
\text { and who are willing to support and become involved in changing current } \\
\text { practices. } \\
\text { - Put together a case and seek out allies and resources. } \\
\text { - Challenge existing diagnostic and treatment practices covertly in the process } \\
\text { of care and overtly within the hospital practices and through the local/national } \\
\text { media. } \\
\text { - Identify those clinicians that will support the case for change within the } \\
\text { hospital those who will consider it and those who resist it at all costs. } \\
\text { - Explore and seek to persuade nursing practitioners and managers to become } \\
\text { involved in the processes of change. } \\
\text { - Explore how current practices, clinical protocols, and guidelines within and } \\
\text { accesses through the current clinical record information system (CRIS) } \\
\text { disenfranchise the patient from taking their own decision making. } \\
\text { - Offer alternatives to these protocols and guidelines based on research and } \\
\text { services provided elsewhere in patient-centered BC hospital and community } \\
\text { services. } \\
\text { - Identify and offer different models of clinical decision making, research } \\
\text { findings on the nature and role of practices and protocols that will empower the } \\
\text { patient decision taker. }\end{array}$ \\
\hline
\end{tabular}




\begin{tabular}{|c|c|}
\hline & Emancipatory Structure and Humanchine Translational Agency \\
\hline 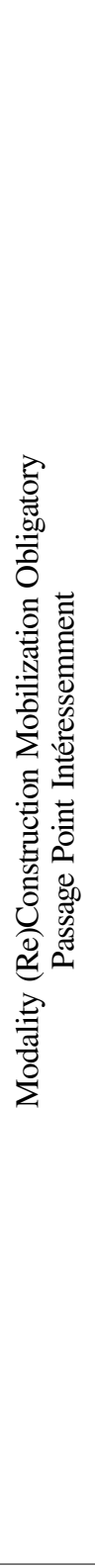 & 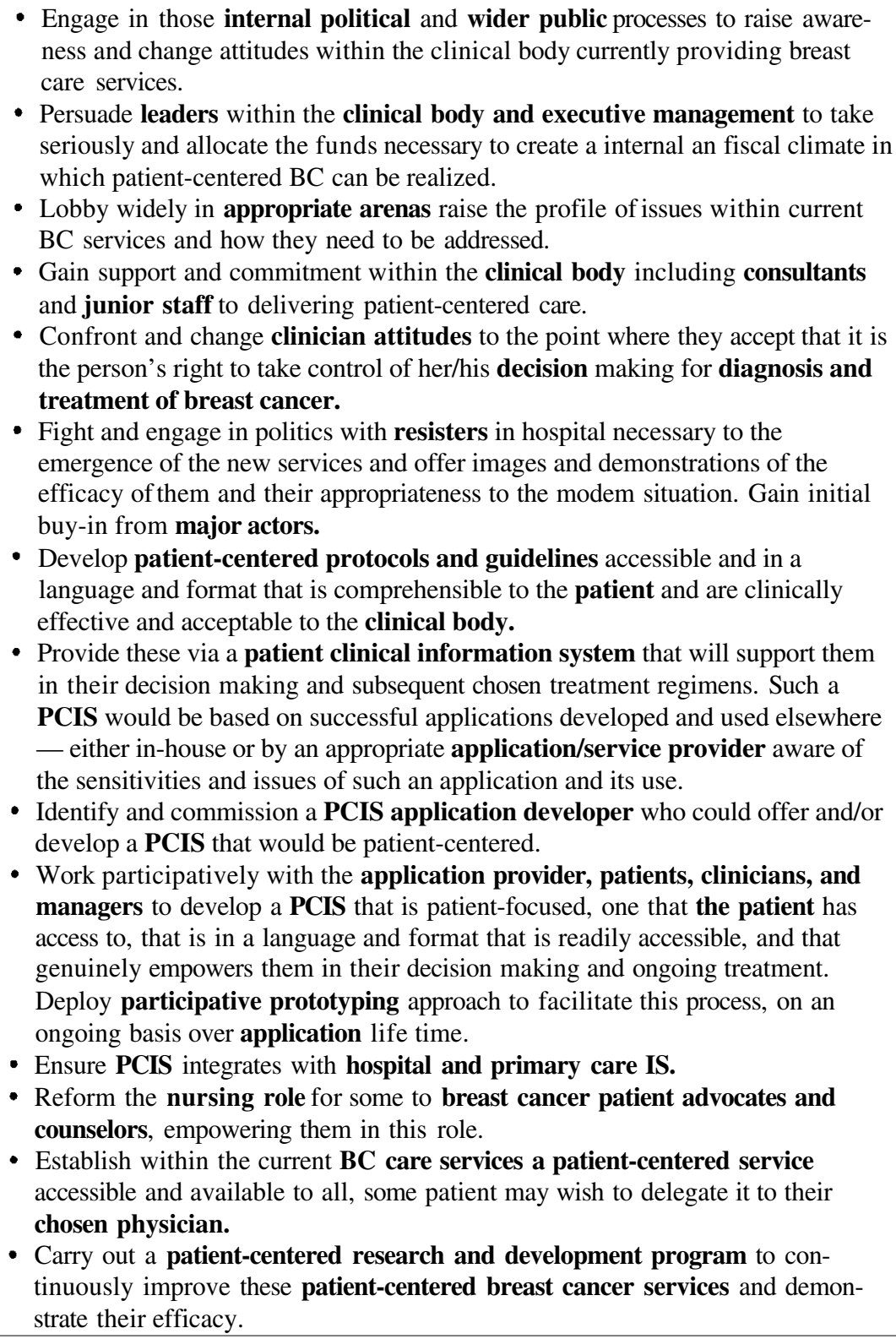 \\
\hline End & $\begin{array}{l}\text { New Actor Network-Humanchine Patient-Centered System (see Figure } 3 \text { and } \\
\text { Table 3) }\end{array}$ \\
\hline
\end{tabular}




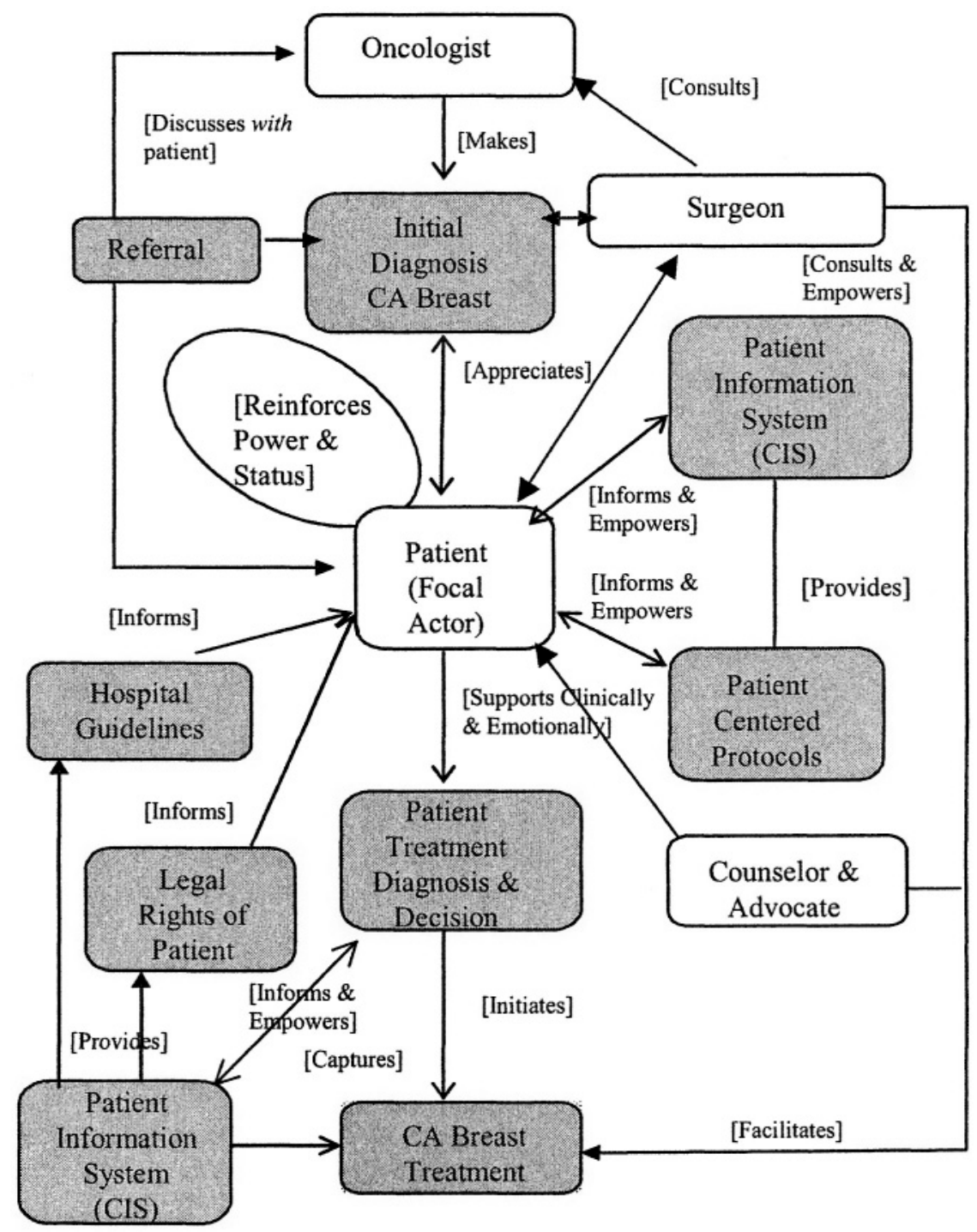

Figure 3. Patient-Centered Humanchine Breast Cancer Treatment Decision-Making Network (human actors are shown not shaded) 
Table 3. The New Structurated Order of Patient-Centered Humanchine Breast Cancer Treatment Decision-Making Actor Network (Human actor $=$ not shaded. Artifact actor $=$ shaded)

\begin{tabular}{|c|c|c|c|}
\hline Structure & Signification & Legitimation & Domination \\
\hline Actor Modality & $\begin{array}{l}\text { Interpretive Scheme } \\
\text { Stocks of Knowledge }\end{array}$ & $\begin{array}{c}\text { Norm } \\
\text { Rights Obligations }\end{array}$ & $\begin{array}{c}\text { Facility } \\
\text { Authorization Allocation }\end{array}$ \\
\hline Referral & $\begin{array}{l}\text { Patient/GP referral } \\
\text { in patient and } \\
\text { clinical terms. }\end{array}$ & $\begin{array}{l}\text { Initiate process of } \\
\text { care by appropriate } \\
\text { referral. }\end{array}$ & $\begin{array}{l}\text { Authorize and allocate } \\
\text { clinicians and resources. }\end{array}$ \\
\hline Oncologist & $\begin{array}{l}\text { Clinical knowledge } \\
\text { linked with diagnos- } \\
\text { tic expertise skills } \\
\text { expressed in clini- } \\
\text { cian's and patient's } \\
\text { language. }\end{array}$ & $\begin{array}{l}\text { Support the patient } \\
\text { with diagnosis, aiding } \\
\text { them in their decision } \\
\text { making. Access/add } \\
\text { patient information } \\
\text { with the patient in the } \\
\text { PCIS. }\end{array}$ & $\begin{array}{l}\text { Authorize surgeon and } \\
\text { allocate theater plus } \\
\text { post-operative resources } \\
\text { in line with diagnosis } \\
\text { and treatment decision. }\end{array}$ \\
\hline $\begin{array}{l}\text { Patient (Focal } \\
\text { Actor) }\end{array}$ & $\begin{array}{l}\text { Expressions of their } \\
\text { insight into their } \\
\text { body, fears, } \\
\text { concerns, and needs } \\
\text { using their own } \\
\text { language and } \\
\text { insights. }\end{array}$ & $\begin{array}{l}\text { Patient right to take } \\
\text { the decision on treat- } \\
\text { ment as to what hap- } \\
\text { pens to their body. } \\
\text { Right to effective } \\
\text { treatment in line with } \\
\text { their decision. Self } \\
\text { obligated to seek deci- } \\
\text { sion and resources or } \\
\text { abrogate them to } \\
\text { clinician. }\end{array}$ & $\begin{array}{l}\text { Right to authorize and } \\
\text { allocate professional and } \\
\text { technical resources in } \\
\text { line with their decision } \\
\text { making on what is most } \\
\text { appropriate treatment for } \\
\text { them. }\end{array}$ \\
\hline Surgeon & $\begin{array}{l}\text { Clinical knowledge } \\
\text { linked with diagnos- } \\
\text { tic and surgical } \\
\text { expertise and skills } \\
\text { expressed in } \\
\text { clinicians and } \\
\text { patient's language. }\end{array}$ & $\begin{array}{l}\text { Obligated to support } \\
\text { the patient in her } \\
\text { clinical decision } \\
\text { making. Right to } \\
\text { disagree and withdraw } \\
\text { from caring for } \\
\text { patient, while offering } \\
\text { alternatives. }\end{array}$ & $\begin{array}{l}\text { Capacity to ensure } \\
\text { clinical human, material, } \\
\text { and informational } \\
\text { resources are available } \\
\text { to the patient and the } \\
\text { procedures undertaken. }\end{array}$ \\
\hline $\begin{array}{l}\text { Diagnosis } \\
\text { CA Breast }\end{array}$ & $\begin{array}{l}\text { Expressed in a way } \\
\text { that is } \\
\text { understandable to } \\
\text { the patient and in } \\
\text { line with current } \\
\text { clinical terruinology. }\end{array}$ & $\begin{array}{l}\text { Medically cogent } \\
\text { diagnosis that is also } \\
\text { commensurate with } \\
\text { the patient's ex- } \\
\text { pressed requirements. }\end{array}$ & $\begin{array}{l}\text { Allocates appropriate } \\
\text { clinical resources. } \\
\text { Authorizes clinical } \\
\text { personnel to make } \\
\text { diagnosis. }\end{array}$ \\
\hline $\begin{array}{l}\text { Patient Clinical } \\
\text { Information } \\
\text { System (PCIS) }\end{array}$ & $\begin{array}{l}\text { Provides clinical } \\
\text { information to } \\
\text { patient and clinician } \\
\text { in appropriate } \\
\text { languages. }\end{array}$ & $\begin{array}{l}\text { Provides information } \\
\text { to patient and clini- } \\
\text { cian in format and } \\
\text { content appropriate to } \\
\text { both. }\end{array}$ & $\begin{array}{l}\text { Allocate access to } \\
\text { clinical information and } \\
\text { clinical artifacts to the } \\
\text { patient and clinicians. } \\
\text { Authorize communi- } \\
\text { cations between patient } \\
\text { and clinicians. }\end{array}$ \\
\hline
\end{tabular}




\begin{tabular}{|c|c|c|c|}
\hline Structure & Signification & Legitimation & Domination \\
\hline Actor ${ }^{\text {Modality }}$ & $\begin{array}{l}\text { Interpretive Scheme } \\
\text { Stocks of Knowledge }\end{array}$ & $\begin{array}{c}\text { Norm } \\
\text { Rights Obligations }\end{array}$ & $\begin{array}{c}\text { Facility } \\
\text { Authorization Allocation }\end{array}$ \\
\hline $\begin{array}{l}\text { Patient's } \\
\text { Treatment } \\
\text { Decision }\end{array}$ & $\begin{array}{l}\text { Siguifies, in lay and } \\
\text { clinical language, } \\
\text { what is needed to be } \\
\text { undertaken to } \\
\text { address patient's } \\
\text { diagnosis. }\end{array}$ & $\begin{array}{l}\text { Give the patient the } \\
\text { right to make a deci- } \\
\text { sion on treatment to } \\
\text { meet her diagnosis. }\end{array}$ & $\begin{array}{l}\text { Allocates to patient the } \\
\text { resources and informa- } \\
\text { tion necessary to address } \\
\text { her treatment decision; } \\
\text { also authorizes access to } \\
\text { clinical expertise } \\
\text { necessary, }\end{array}$ \\
\hline $\begin{array}{l}\text { Patient- } \\
\text { Centered } \\
\text { Protocols }\end{array}$ & $\begin{array}{l}\text { Provides a road map } \\
\text { for patient use in } \\
\text { support of her } \\
\text { clinical decision } \\
\text { making on treatment, } \\
\text { commensurate with } \\
\text { effective practice. }\end{array}$ & $\begin{array}{l}\text { Enshrines the rights } \\
\text { and obligations of } \\
\text { patient and clinician } \\
\text { necessary to under- } \\
\text { take a diagnosis and } \\
\text { proceed to treatment. }\end{array}$ & $\begin{array}{l}\text { Allocates resources and } \\
\text { authorizes the clinical } \\
\text { personnel necessary to } \\
\text { realizing the patient's } \\
\text { decision on breast } \\
\text { cancer treatment. }\end{array}$ \\
\hline $\begin{array}{l}\text { Hospital } \\
\text { Guidelines }\end{array}$ & $\begin{array}{l}\text { Provides, in lay and } \\
\text { technical language, } \\
\text { those clinician prac- } \\
\text { tices a patient can } \\
\text { expect from a } \\
\text { clinician. }\end{array}$ & $\begin{array}{l}\text { Set out the rights and } \\
\text { obligations of both } \\
\text { patient and clinician } \\
\text { with respect to } \\
\text { treatment and } \\
\text { services. Hospital } \\
\text { legitimized. }\end{array}$ & $\begin{array}{l}\text { Provides a framework to } \\
\text { guide the patient in the } \\
\text { allocation of resources } \\
\text { and authorization of } \\
\text { personnel. }\end{array}$ \\
\hline $\begin{array}{l}\text { Legal Rights of } \\
\text { Patient }\end{array}$ & $\begin{array}{l}\text { Sets, in lay and tech- } \\
\text { nical language, the } \\
\text { rights of the patient } \\
\text { about diagnosis and } \\
\text { treatinent. }\end{array}$ & $\begin{array}{l}\text { Identifies what the } \\
\text { patient and clinician } \\
\text { can/cannot expect of } \\
\text { their legal rights } \\
\text { within clinical } \\
\text { practice. Enshrined in } \\
\text { the constitution. }\end{array}$ & $\begin{array}{l}\text { Sets out the resources, } \\
\text { personnel, and artifacts } \\
\text { that the patient and the } \\
\text { clinician can draw on in } \\
\text { protecting their legal } \\
\text { rights. }\end{array}$ \\
\hline Treatment & $\begin{array}{l}\text { Provides a descrip- } \\
\text { tion in lay and clini- } \\
\text { cal professional } \\
\text { terms of the } \\
\text { treatment decided } \\
\text { upon and how it will } \\
\text { be carried out. }\end{array}$ & $\begin{array}{l}\text { Sets out the rights and } \\
\text { obligations of the } \\
\text { humans and artifacts } \\
\text { undertaking the } \\
\text { treatment to address } \\
\text { the patient's } \\
\text { diagnosis. }\end{array}$ & $\begin{array}{l}\text { Allocates the physical } \\
\text { and authorizes the } \\
\text { human and professional } \\
\text { resources necessary to } \\
\text { materialize patient } \\
\text { treatment decision. }\end{array}$ \\
\hline
\end{tabular}

We recognize that the template for analysis set out here is tentative, naive, and overly linear, given the complexity of real-world translations. We offer it as a point of departure, acknowledging that it would change through the demands of, and reflections on, future research and development using StructurANTion. The diagrammatic translations are themselves part of the cognitive development of ideas about the changes and, therefore, are an essential component in our understanding of that change. We now consider each stage in turn. 


\subsection{Stage 1: The Existent Network its Actors, Structures, and Modalities}

Within the proposed StructurANTional analysis, the first task is to represent the structurated order existent within the initial, and problematized, organizational actor network(s). This entails delineating the actors and the complimentary modalities oftheir common structures that are drawn on in the pursuit of individual and collective agency. For this network, these are shown in Table 2, with the nonhuman elements shaded. From this table, it could be inferred that machines and artifacts have structures. We will argue, in subsequent papers, that this is not the case. Rather, it is at the level of modality that humans and machines are conjoined (or not) within the network. For example, the clinical information system hosts diagnostic protocols whose significating knowledge base and language are commensurate with those of the surgeon and oncologist, but not the patient. However, because the humanchine duality has a human component within it and they do have structures, then the humanchine also has structures that are recursively reproduced through its agency; as per Giddens' (1984a) structuration theory. The question for future research is how these structures are mobilized (or not) through effectively integrated human and nonhuman modalities via the double mangle of Jones (1999).

Figure 2 identifies the network's actors and their relationships. Table 1 presents the modalities of this network's structures inherent within humans and inscribed within is nonhuman artifacts and technologies.

The power of the network's mutually reinforcing structurated order within the modalities of both humans and nonhumans is epitomized here by the clinical protocol. Such protocols embody all three modalities and are enacted by humans and nonhumans. When enacted by the physician, they sanction the allocation of clinical resources, and authorization of clinical practitioners' behaviors; when followed, they legitimate clinical decision making and obligations, they embed clinical knowledge, and they are expressed in clinical language. They also allocate the patient to a passive role of the recipient of the decision. The protocols also reside within the modalities of the clinical information system and the physician's mind and are made manifest in their joint agency when the humans and technologies in the network enact it to arrive at a clinical decision.

Figure 2 illustrates how the actors within a network are identified and their relationships are represented. In Table 1, the modalities of the structurated order of the existent clinician-dominated actor network are captured and represented. Table 2 then sets out the process of translation of the actors from within the clinician-dominated actor's network to one in which a patient-centered structurated order presides.

\subsection{Stage 2: Actor Behavior and Relationships}

The next task of the analysis is to explore the relationships and interactions of the actors as they draw upon these modalities to constitute the network and the collective agency that, in this case, arrives at a clinician-made treatment decision for the patient (see Figure 2). Note how in Figure 2 all of the human and machine actors convene around the focal actor, the surgeon, to address their problematization of the need for a treatment diagnosis for their patient. The clinical information system, along with the 
clinical protocols, are particularly influential in sustaining this structurated order as they have the surgeon's and other clinician's interests inscribed within their modalities and functional behavior. This is manifest not only in their exclusive access to the protocols and the passive role of the patient within them but the artifact of clinical terminology in which they are expressed. The relationships they have with each other all reflect the position of power the surgeon has within the network. They are all geared up to proclaim the surgeon as the center of the network. In doing so, this subordinates the patient to that of passive recipient of its treatment decision.

\subsection{Stage 3: Translation of the Existing Structurated Order}

This stage of the analysis (see Table 2) focuses on what transpires as a result of the problematization and deconstruction of the network's existent structurated order of the surgeon focal actor and the emergence of a new one, the patient-focused actor network.

In this case, the stage consists of an exploration of the problematization of the current clinician-centered actor network by a newly emergent focal actor: here the patient along with her clinician and technological allies. It is a struggle for power within the network. The actors are shown in bold in Table 2. This results in the current clinician-centered network's deconstruction and its subsequent (re)constructional translation into a patient-centered clinical decision making actor network, all of which (see Table 2) is achieved through the mobilization of a multiplicity of other actors facilitated by the emancipatory structure inherent within the existent network. They form a problematization network, temporarily convened to by the focal actor. When mobilized they effect change in the existing network. Some, but not all of them, then are further translated to constitute the patient-centered humachine breast cancer treatment decisionmaking actor network.

The demonstrational analysis in this paper would suggest that translation is inevitable and mono-directional. In reality, this is far from the case. From an initial problematization, the trajectory of translation is potentially poly-directional, multidimensional, and its outcome unclear. The emergent structurated order could be as easily at odds with the initiating problematization as in concert. Both research and development should anticipate the uncertainty of translation within real-world situations.

\subsection{Stage 4: Delineate the Behaviors of Actors in the Newly Emergent Network}

Having identified the moments of translation, the next stage is to capture or anticipate its outcome. The emergent actor network (see Figure 3) in this example centers on supporting the patient as the focal actor, with new roles for the surgeon in enabling them to make the decision and the nurses acting as counselor and advocate. The IS provides patients with information access; providing them with graphical tools and protocols in a language that is both accessible to support their own decisions, yet is also clinically cogent. This newly emergent patient-centered structurated order is delineated in Table 3. 


\subsection{Stage 5: Identify the Humans and Machine Artifacts of the Actor Network and Their Modalities Within the Newly Emergent Network}

Having, either through research or design, identified the newly translated actor network and its agency, the next stage is to identify the modalities of the humans and artifacts within the network. This is done in order to define the structurated order of a newly emergent network. For research, they provide insights into the translations of actor networks, and their orders of agency and structure. If, however, the StructurANTion framework is used to underpin practice, then this analysis could support a focal actor in addressing their chosen problematization. These are set out in Table 3, which reveals how the modalities of the new patient centered network have changed and how they manifest themselves in how the humans behave and also, of relevance here, how the PCIS changes in its functionality and modalities.

\section{CONCLUSION}

This paper set out to argue for and illustrate the concept of the humanchine duality of the actor network as being at the focus of IS research within the context of organizational development. Information technologies are, we assert, themselves nonhuman actors. They convene together with the human beings that use them to constitute humanchine IS. Such systems are themselves hybrid actors within a wider humanchine network that collectively exhibits agency (for example, breast cancer decision-making). Such humanchine networks persist and change over time and space. The neologistic hybrid, the humanchine, has been adopted to capture the essential duality of the human and nonhuman actors who as networks exhibit a collective agency. This analysis is based on the authors' StructurANTion framework, itselfa hybrid theory whose own neologism reflects the humanchine duality of its core concept.

The discussion here has focused on the manner in which such networks change dramatically. In StructurANTion terms, they are translated by a focal actor invoking a network's emancipatory structure. The result is a new network possessed of a structurated order that is markedly different from its network progenitor. The illustration used was the movement from a clinician-centered breast cancer decision-making actor network to one centered on the woman patient as the focal actor. The ramifications for the technology actor and its human users are that structural modalities (embedded within their minds) and its functionality have to change. Drawing on the StructurANTion framework, IS as a practice needs to both understand the its own role within the existing network and to work with those who are affecting the network's translation, to create a new technological application whose modalities and functionality are aligned with the emergent network. To achieve this in practice, our next step is another, greater challenge. To paraphrase Machiavelli, from the early explorations of ANT, "It must be considered that there is nothing more difficult to carry out nor more doubtful of success nor more dangerous to handle than to initiate a new [structurated] order of things." 


\section{REFERENCES}

Atkinson, C. J. A Project to Support the Combined Development of the Integrated Patient Management System (IPMS) and Clinical Practice in XXX NHS Trust, Report to the NHS Executive Information Management Group and ChiefExecutive of the XXX NHS Trust, 1997.

Atkinson, C. J., and Brooks, L. S. "StructurANTion: A Theoretical Framework for Integrating Human and IS Research and Development," in J. Ross and D. Galletta (Eds.), Proceedings of the Ninth Americas Conference on Information Systems, Tampa, FL, 2003, pp. 28952902.

Atkinson, C. J., and Peel, V. J. "Transforming a Hospital through Growing, Not Building, an Electronic Patient Record System," Methods of Information in Medicine (37), 1998, pp. 206310.

Callon, M. "Some Elements of a Sociology of Translation: Domestication of the Scallops and the Fishermen," in J. Law (Ed.), Power, Action and Belief: A New Sociology of Knowledge, London: Routledge and KeeganPaul, 1986.

Giddens, A. Central Problems in Social Theory, Basingstoke, UK: Macmillan, 1979.

Giddens, A. The Constitution of Society, Cambridge, UK: Polity Press, 1984a.

Giddens, A. The Constitution of Society: Extracts and Annotations, Berkeley. University of California Press, 1984b.

Jones, M. "Information Systems and the Double Mangle: Steering a Course Through the Scylla of Embedded Structure and the Charybdis of Strong Symmetry," in T. J. Larsen, L. Levine, and J. I. DeGross (Eds.), Information Systems: Current Issues and Future Changes, Laxenburg, Austria: IFIP, 1999, pp. 287-302.

Jones, M., and Karsten, H. "Review: Structuration Theory and Information Systems Research," Research Paper No. 2003/11, Judge Institute of Management Studies, Cambridge University, 2003.

Latour, B. "Gabriel Tarde and the End of the Social," in P. Joyce (Ed.), The Social and its Problems, London: Routledge, 2001.

Latour, B. Pandora's Hope: Essays on the Reality of Science Studies, Boston: Harvard University Press, 1999.

Latour, B. Science in Action, Boston: Harvard University Press, 1987/

Law, J., and Mol, A. "Situating Technoscience: An Inquiry into Spatialities," unpublished working paper, Centre for Science Studies and the Department of Sociology, Lancaster University, and the Department of Philosophy, the University of Twente, 2000.

Law, J., and Urry, J. "Enacting the Social," Working Paper, Centre for Science Studies and Sociology Department, Lancaster University, 2002.

Newton, H. Newton's Telecom Dictionary: Covering Telecommunications, Networking, the Internet, Computing, and Information Technology, Gilroy, CA: CMP Books, 2003.

Tatnall, A., and Gilding, A. "Actor-Network Theory and Information Systems Research," in Proceedings of the $10^{\text {th }}$ Australasian Conference on Information Systems, Victoria University of Wellington, Wellington, New Zealand, 1999, pp. 955-966.

Walsham, G. "Actor-Network Theory and IS Research: Current Status and Future Prospects," in A. S. Lee, J. Liebenau, and J. I. DeGross (Eds.), Information Systems and Quality Research, London: Chapman \& Hall, 1997, pp. 466-480.

\section{ABOUT THE AUTHORS}

Laurence Brooks is a lecturer in the Department of Information Systems and Computing at Brunel University. He previously was a lecturer in the Department of Computer Science at the 
University of York and held a research position in the Judge Institute of Management Studies, Cambridge University. He gained a Ph.D. in Industrial Management from the University of Liverpool and a B.Sc. in Psychology from the University of Bristol. His current research interests are in the role that social theory might play in contributing to our understanding of information systems in areas such as health information systems and collaborative work support systems. He is a member of the UK Academy for Information Systems (UKAIS) national board. Laurence can be reached at laurence.boroks@brunel.ac.uk.

Chris Atkinsonis a senior lecturer in Information Systems in the UMIST Department of Computation. Until recently he was with Brunel University's Department of Information Systems and Computing Science. Originally a civil engineer, he undertook an M.Sc. and Ph.D. at Lancaster University in soft systems with a particular focus on systemic metaphor and its role in organizational problem solving. He has worked as both an academic and practitioner, focusing on how to integrate information systems development and organizational change, especially within healthcare settings. To that end, he has evolved and extensively deployed the Soft Information Systems and Technologies Methodology (SISTeM). Actor-network theory has recently emerged as an important framework for research, practice and methodological development. Its integration with structuration theory has proved fruitful as a further area for research and development. His field of study and practice has centered on working with multi-professional teams, clinicians, managers, and information systems practitioners in affecting integrated organizational development. Chris may be contacted via christopher.atkinson@brunel.ac.uk. 